Review

\title{
Chemopreventive effect and lack of genotoxicity and mutagenicity of the exopolysaccharide botryosphaeran on human lymphocytes
}

\author{
M. Malini a,*,1 , M.S. Camargo ${ }^{\text {b }}$, L.C. Hernandes ${ }^{\text {c }}$, C.G. Vargas-Rechia ${ }^{\text {d }}$, E.A. Varanda ${ }^{\text {b }}$, A.M. Barbosa ${ }^{\text {e, }}$, \\ R.F.H. Dekker ${ }^{\text {e }}$, S.T. Matsumoto ${ }^{\text {f }}$, L.M.G. Antunes ${ }^{\text {c }}$, I.M.S. Cólus ${ }^{\text {a }}$
}

a Departamento de Biologia Geral, Centro de Ciências Biológicas - Universidade Estadual de Londrina, Rodovia Celso Garcia Cid, Km 380, CEP 86.057-970, Londrina, , PR, Brazil

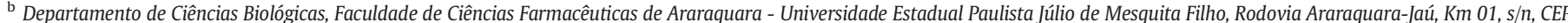
14.800-903, Araraquara, SP, Brazil

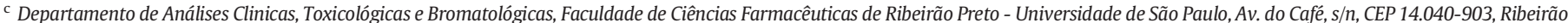
Preto, SP, Brazil

d Departamento de Física e Química, Faculdade de Ciências Farmacêuticas de Ribeirão Preto - Universidade de São Paulo, Av. do Café, s/n, CEP 14.040-903, Ribeirão Preto, SP, Brazil

e Biorefining Research Institute, Lakehead University, Thunder Bay, Ontario P7B 5E1, Canada

${ }^{\mathrm{f}}$ Departamento de Ciências Biológicas, Centro de Ciências Humanas e Naturais - Universidade Federal do Espírito Santo, Avenida Fernando Ferrari, 514, CEP 29.075-910, Vitória, ES, Brazil

\section{A R T I C L E I N F O}

\section{Article history:}

Received 30 March 2016

Received in revised form 20 June 2016

Accepted 30 June 2016

Available online 5 July 2016

\section{Keywords:}

Ames test

Comet assay

$(1 \rightarrow 3)(1 \rightarrow 6)-\beta-D-g l u c a n$

Jurkat cells

Human T lymphocytes

Antigenotoxicity

\begin{abstract}
A B S T R A C T
Carbohydrate biopolymers of fungal-origin are an important natural resource in the search for new bioagents with therapeutic and nutraceutical potential. In this study the mutagenic, genotoxic, antigenotoxic and antioxidant properties of the fungal exopolysaccharide botryosphaeran, a $(1 \rightarrow 3)(1 \rightarrow 6)-\beta$-D-glucan, from Botryosphaeria rhodina MAMB-05, was evaluated. The mutagenicity was assessed at five concentrations in Salmonella typhimurium by the Ames test. Normal and tumor (Jurkat cells) human T lymphocyte cultures were used to evaluate the genotoxicity and antigenotoxicity (Comet assay) of botryosphaeran alone and in combination with the mutagen methyl methanesulfonate (MMS). The ability of botryosphaeran to reduce the production of reactive oxygen and nitrogen species (RONS) generated by hydrogen peroxide was assessed using the CM$\mathrm{H}_{2}$ DCFDA probe in lymphocyte cultures under different treatment times. None of the evaluated botryosphaeran concentrations were mutagenic in bacteria, nor induced genotoxicity in normal and tumor lymphocytes. Botryosphaeran protected lymphocyte DNA against damage caused by MMS under simultaneous treatment and post-treatment conditions. However, botryosphaeran was not able to reduce the RONS generated by $\mathrm{H}_{2} \mathrm{O}_{2}$. Besides the absence of genotoxicity, botryosphaeran exerted a protective effect on human lymphocytes against genotoxic damage caused by MMS. These results are important in the validation of botryosphaeran as a therapeutic agent targeting health promotion.
\end{abstract}

(c) 2016 Elsevier Ltd. All rights reserved.

\section{Contents}

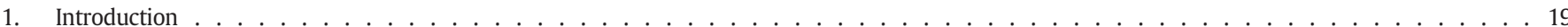

2. Material and methods . . . . . . . . . . . . . . . . . . . . . . . . . . . . . 19

2.1. Microorganism and culture conditions . . . . . . . . . . . . . . . . . . . . . . . . . . . . . . . . 19

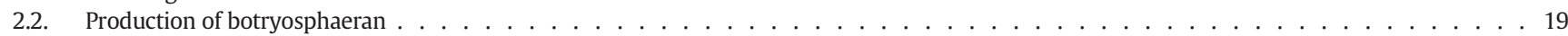

2.3. Source of lymphocytes . . . . . . . . . . . . . . . . . . . . . . . . . . . . . . . . . . 20

* Corresponding author at: Departamento de Biologia Geral - CCB, Universidade Estadual de Londrina - UEL, Rodovia Celso Garcia Cid, PR (445), Km 380, CEP 86057-970 Londrina, Paraná, Brazil.

E-mail addresses: maressa.malini@gmail.com (M. Malini), marianasantoro@gmail.com (M.S. Camargo), livia.hernandes@yahoo.com.br (L.C. Hernandes), cvrechia@fcfrp.usp.br (C.G. Vargas-Rechia), eavaranda@gmail.com (E.A. Varanda), anelibarbosa@gmail.com (A.M. Barbosa), rdekker@lakeheadu.ca (R.F.H. Dekker), siltamie@gmail.com (S.T. Matsumoto), lusania@fcfrp.usp.br (L.M.G. Antunes), ilcecolus@gmail.com (I.M.S. Cólus).

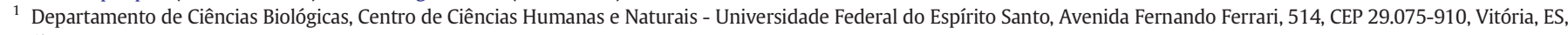
Brazil.

${ }^{2}$ Departamento de Química, Centro de Ciências Exatas - Universidade Estadual de Londrina, Rodovia Celso Garcia Cid, PR 445, Km 380, CEP 86.057-970, Londrina, PR, Brazil. 
2.3.1. Lymphocyte culture conditions and treatments . . . . . . . . . . . . . . . . . . . 20

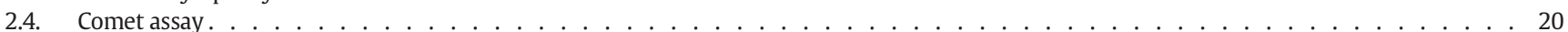

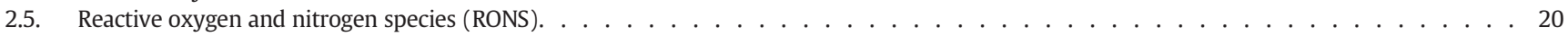

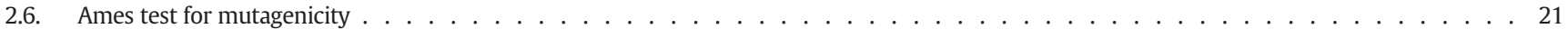

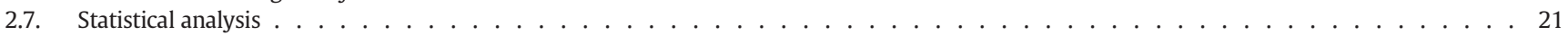

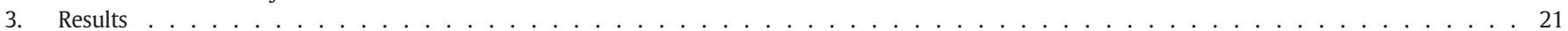

3.1. Genotoxicity and antigenotoxicity . . . . . . . . . . . . . . . . . . . . . . . . 21

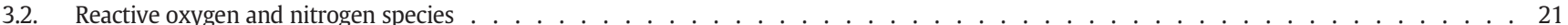

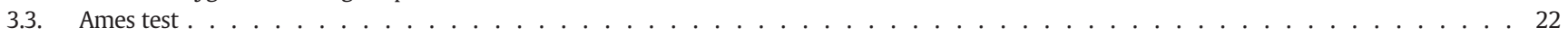

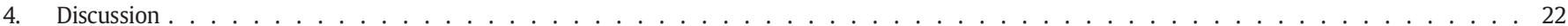

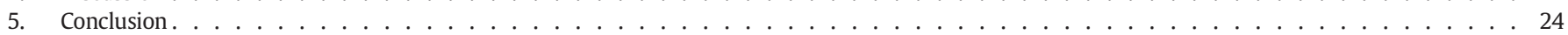

Transparency document . . . . . . . . . . . . . . . . . . . . . . . . . . . . . . . . . . 24

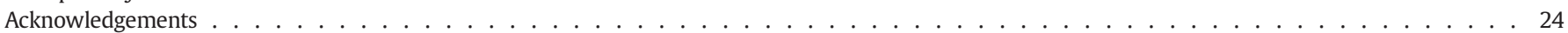

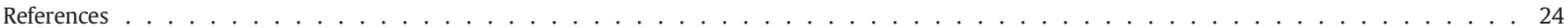

\section{Introduction}

Carbohydrate biopolymers (polysaccharides) of fungal-origin are an important natural resource in the search for new agents with therapeutic potential. Among them are the $\beta$-glucans, notably the $(1 \rightarrow 3)(1 \rightarrow 6)-\beta-D$-glucans, that are known to modify biological responses (Bohn and BeMiller, 1995), and play roles in chemoprevention, and can manifest immunomodulatory and antitumor activities, among others (Kagimura et al., 2015; Kirkland et al., 2011). $\beta$-D-Glucans of the $(1 \rightarrow 3)$-type are not digested by enzymes such as the $\beta$ - $(1 \rightarrow 3)$ glucanases, which are absent from the gastrointestinal tract of mammals. Thus, they survive longer in the tissues of mammals, and can therefore be a candidate bioagent in treating cancers (Miura et al., 1996). Their ability to non-specifically activate the cellular and humoral components of the host immune system is well documented in the literature, see for example, (Williams, 2009). Accordingly, this activation leads to the increased functional activity of immune cells such as macrophages, mononuclear cells and neutrophils (Liang et al., 1998). Despite the studies that show the absence of toxicity of these compounds and their derivatives (Kagimura et al., 2015; Miranda-Nantes et al., 2011; Miranda et al., 2008; Roupas et al., 2012; Weng et al., 2011), the evidence of the absence of risk to health and the mechanism by which the $(1 \rightarrow 3)-\beta$-D-glucans exert their effects on mammalian cells are key to their validation as bioactive agents.

The exopolysaccharide (EPS) botryosphaeran is of the $(1 \rightarrow 3)(1 \rightarrow 6)-\beta$-D-glucan type and is secreted by the fungus, Botryosphaeria rhodina MAMB-05. Botryosphaeran consists of a linear backbone chain of D-glucose residues linked by $(1 \rightarrow 3)$ - $\beta$-glucosidic bonds, with side-branches comprising glucose and gentiobiose linked through ( $1 \rightarrow 6)$ - $\beta$-glucosidic bonds (Barbosa et al., 2003). It is soluble in water and forms gels and viscous solutions that may favor its commercial applications in different sectors such as health, biotechnology, food, pharmaceutical and cosmetology (Kagimura et al., 2015).

Studies from our research groups have evaluated the biological effects of botryosphaeran. This $(1 \rightarrow 3)(1 \rightarrow 6)-\beta$-D-glucan (i) did not present mutagenic activity (micronucleus test) in mice, and exhibited strong antimutagenic activity (Miranda et al., 2008); (ii) promoted hypoglycemic activity reducing the levels of plasma glucose in diabetes-induced rats by 52\%, and reduced LDL-cholesterol levels in hyperlipidaemic-conditioned rats by $18 \%$ (Miranda-Nantes et al., 2011); (iii) exerted an antiproliferative effect in breast cancer MCF-7 cells that was associated with apoptosis, necrosis and oxidative stress (Queiroz et al., 2015); (iv) in combination with the antineoplastic agent, doxorubicin, botryosphaeran was selective for leukemic T lymphocyte cells (Malini et al., 2015). The molecular mechanisms of action of botryosphaeran appear to be involved in the repression of genes related to the G1 phase of the cell cycle (Malini et al., 2015). When derivatized by sulfonylation, the sulfonated biopolymer exhibited anticoagulant and antithrombotic activities (Brandi et al., 2011). In addition, botryosphaeran was found to possess free radical scavenging properties and antioxidant activity (Giese et al., 2015). In another study with a different B. rhodina strain (RCYU 30101), botryosphaeran demonstrated the ability to activate the lymphoblastogenesis process (Weng et al., 2011).

Understanding the mechanisms by which botryosphaeran exerts its chemoprotective effect is important in validating this $\beta$-glucan as a therapeutic agent. Studies on botryosphaeran's ability to inhibit the genotoxic effect caused by several mutagens are key to understanding its mechanism of action. The antimutagenic activity consists of the peculiar ability of a substance to reduce the frequency of spontaneous or induced mutations regardless of the mechanism involved (Von Borstel et al., 1996). Słoczyńska et al. (2014) recently proposed that various classes of compounds can be distinguished, such as compounds with antioxidant activity; compounds that inhibit the activation of mutagens; blocking agents; as well as compounds characterized with multiple mechanisms of action.

It is necessary and important to use in vitro tests employing normal and tumor cells in order to rapidly assess the selectivity of botryosphaeran as a therapeutic agent, given its biological effects, and the potential applications of this EPS described in the literature by our research group.

In the present study the objectives were to investigate: (i) the effects of the treatment with botryosphaeran alone, or in combination with the mutagen, methyl methanesulfonate (MMS), on normal and tumor (Jurkat cells) human T lymphocytes in order to evaluate its genotoxic and chemoprotective effects on these cell types; (ii) the possible mutagenicity of botryosphaeran assessed by the Ames test on different Salmonella typhimurium strains; and (iii) the antioxidant effect against $\mathrm{H}_{2} \mathrm{O}_{2}$-induced production of RONS (reactive oxygen and nitrogen species) on normal and tumor lymphocytes.

\section{Material and methods}

\subsection{Microorganism and culture conditions}

Botryosphaeria rhodina (MAMB-05 isolate) was grown by submerged fermentation (SmF) on sucrose as sole carbon source for $72 \mathrm{~h}$ at $28^{\circ} \mathrm{C}$ as described by Steluti et al. (2004).

\subsection{Production of botryosphaeran}

Following the growth of the fungus, the mycelium was removed by centrifugation $(1250 \mathrm{~g} / 15 \mathrm{~min})$ and the supernatant recovered to which was then added three volumes of isopropanol, and left to stand overnight at $4{ }^{\circ} \mathrm{C}$. The precipitate was recovered by centrifugation, resolubilized in water with gentle heating, and then dialyzed exhaustively against water for $48 \mathrm{~h}$ at $4{ }^{\circ} \mathrm{C}$. Thereafter, the dialyzed solution 
containing botryosphaeran was lyophilized, and the dried powder stored at $-20^{\circ} \mathrm{C}$ until used.

A stock solution of botryosphaeran was prepared by solubilizing $3.0 \mathrm{~g}$ of botryosphaeran in $1 \mathrm{~L}$ of sterile water, and the solution sterilized by autoclaving $\left(121^{\circ} \mathrm{C} / 20 \mathrm{~min}\right)$ and stored at $4{ }^{\circ} \mathrm{C}$.

\subsection{Source of lymphocytes}

The biological effects of botryosphaeran were assessed in human lymphocyte cultures (normal and leukaemic - Jurkat cells). Normal lymphocytes were obtained by collecting $10 \mathrm{~mL}$ of peripheral blood from three healthy male individuals aged 27, 32 and 34 years. Each person was interviewed for possible confounding factors such as smoking, alcohol drinking, medicine intake and exposure to radiation and/or chemical mutagens. All volunteers signed the free and informed consent form approved by the Ethics Committee on Human Research of FCFRP - University of São Paulo, Brazil (CEP/FCFRP n. 314).

Jurkat cells, a lymphoblastoid cell line, were kindly provided by Hemocentro do Hospital das Clínicas da Faculdade de Medicina de Ribeirão Preto, Universidade de São Paulo, (Brazil), and were kept under liquid nitrogen $\left(-196^{\circ} \mathrm{C}\right)$ until required.

\subsubsection{Lymphocyte culture conditions and treatments}

Normal lymphocytes were isolated from peripheral blood using Ficoll Histopaque® 1077 (Sigma-Aldrich, St. Louis, MO, USA) immediately after being collected from volunteers in all of the experiments described in the present study. Jurkat cells were thawed and used between the 3rd and 9th passages. Both cell types were cultured in $15 \mathrm{~mL}$ sterile conical tubes (Corning, Lowell, MA, USA) during the cytogenetic assays, and in the biochemical assays were cultured in 96-well Microplates (Corning). The cells were cultured for $24 \mathrm{~h}$ in RPMI 1640 culture medium (Sigma-Aldrich, St. Louis, MO, USA) supplemented with $20 \%$ fetal bovine serum (Gibco, Carlsbad, CA, USA); $0.01 \mathrm{mg} / \mathrm{mL}$ streptomycin (Sigma-Aldrich); $0.005 \mathrm{mg} / \mathrm{mL}$ penicillin (Sigma-Aldrich); and $2.38 \mathrm{mg} / \mathrm{mL}$ HEPES (Sigma-Aldrich) in all experiments. The tubes and plates were kept in an incubator at $37{ }^{\circ} \mathrm{C}$ with $5 \% \mathrm{CO}_{2}$ atmosphere and placed on $45^{\circ}$ slopes, and lightly agitated periodically.

Three non-cytotoxic concentrations of botryosphaeran (7.5, 30 and $100 \mu \mathrm{g} / \mathrm{mL}$ ) were used to evaluate genotoxic and antigenotoxic activities in normal and tumor (Jurkat) human T lymphocytes. These concentrations were selected based upon a study (unpublished from our research group) on MTT assays (Mosmann, 1983) conducted on Chinese hamster lung fibroblast (V79) and in hepatocarcinoma of Rattus norvegicus (HTC) cell lines. This study showed that botryosphaeran was not cytotoxic towards each of these cell lines over the 10 concentrations (ranging from 7.5 to $600 \mu \mathrm{g} / \mathrm{mL}$ ) examined. From the MTT results obtained in that study, three concentrations of botryosphaeran (7.5, 30.0 and $100.0 \mu \mathrm{g} / \mathrm{mL}$ ) were chosen to perform all the tests as reported here.

Approximately $1 \times 10^{5}$ cells were exposed to botryosphaeran alone, or in combination with the mutagenic agent, MMS $(10 \mu \mathrm{M})$. The duration of treatment with botryosphaeran was for $20 \mathrm{~h}$, and started $28 \mathrm{~h}$ after the cells had been cultured. Cell cultures were harvested and the cells fixed $48 \mathrm{~h}$ after onset.

In the post-treatment protocol, both types of lymphocytes were cultured for $24 \mathrm{~h}$, and then treated with MMS $(10 \mu \mathrm{M})$ for $4 \mathrm{~h}$. The cells were then washed with PBS, and fresh culture medium and botryosphaeran solution were added, and the cells were left for a further $20 \mathrm{~h}$ before the experiment was terminated at the 48th hour. In the simultaneous treatment experiment, after $44 \mathrm{~h}$ of the beginning of cell culture, the lymphocytes were treated with botryosphaeran and MMS for $4 \mathrm{~h}$; then fresh medium was added to the cells and they were cultured for a further $4 \mathrm{~h}$, with the cells fixed at the $48 \mathrm{th} \mathrm{h}$. An aliquot of the cell suspension was used at the end of the treatment procedures to analyze for cell viability by the Trypan Blue exclusion method
(Strober, 2001). Only cultures showing cell viability of $\geq 80 \%$ were considered to be valid.

\subsection{Comet assay}

The comet assay was performed according to Tice et al. (2000) with modifications. Briefly, $1 \times 10^{5}$ of both lymphocyte cell types were mixed with Low Melting Point agarose (Sigma-Aldrich) and transferred onto pre-coated slides with a basic layer of Normal Melting Point agarose (Sigma-Aldrich) $1.5 \%(\mathrm{w} / \mathrm{v})$ in PBS ( $\mathrm{pH} 7.4)$ and then covered with glass coverslips and cooled at $4{ }^{\circ} \mathrm{C}$ for $20 \mathrm{~min}$. Next the coverslips were removed and the slides immersed in cold alkaline lysis solution (2.5 M NaCl, 10 mM Tris-HCl buffer (pH 10.0), 100 mM EDTA, 10\% dimethyl sulfoxide, $1 \%$ Triton $\mathrm{X}-100, \mathrm{pH} 10.0$ ) for one hour at $4{ }^{\circ} \mathrm{C}$ in the dark. At the end of lysing period, the slides were transferred to an electrophoresis chamber containing a high $\mathrm{pH}$ (13.0) electrophoresis solution (300 $\mathrm{mM} \mathrm{NaOH}, 1 \mathrm{mM}$ EDTA) and incubated at $4{ }^{\circ} \mathrm{C}$ for $20 \mathrm{~min}$ to allow the DNA to unwind. A current of $25 \mathrm{~V}: 300 \mathrm{~mA}(1.25 \mathrm{~V} / \mathrm{cm})$ was applied for $20 \mathrm{~min}$, after which, the slides were submerged in a neutralization buffer ( $400 \mathrm{mM}$ Tris-HCl, $\mathrm{pH} 7.5$ ) for $15 \mathrm{~min}$, followed by drying at room temperature, and then fixed in 100\% ethanol for $5 \mathrm{~min}$.

The slides were then stained with $50 \mu \mathrm{L}$ GelRed $₫$ solution (Biotium, Hayward, CA, USA) (15 $\mu \mathrm{L}$ of GelRed ${ }^{\circledR} 10,000 \times$ in water, $5 \mathrm{mM}$ of $1 \mathrm{M}$ $\mathrm{NaCl}$, and $45 \mathrm{~mL}$ distilled water) and examined by fluorescent microscopy (Nikon-Brazil) using $488 \mathrm{~nm}$ (excitation) and $515 \mathrm{~nm}$ (emission) barrier filters, and a $40 \times$ objective lens. One hundred (100) nucleoids were analyzed per treatment, and DNA damage was quantified visually and classified into four classes (0,1,2 and 3) according to the size of the tails (Kobayashi et al., 1995). The cytological analyses were always performed by the same investigator under blind conditions. The score (Manoharan and Banerjee, 1985), the frequency of damaged cells (DC) and the percentage reduction (\% R) of damage (Waters et al., 1990), were calculated according to the formulae presented below, wherein $\mathrm{N}$ is the number of analyzed cells in each class, and PC and NC correspond, respectively, to the positive and the negative control groups.

$$
\begin{aligned}
& \text { Score }=\frac{\left(0 \mathrm{X} \mathrm{N}_{0}\right)+\left(1 \mathrm{X} \mathrm{N}_{1}\right)+\left(2 \mathrm{X} \mathrm{N}_{2}\right)+\left(3 \mathrm{X} \mathrm{N}_{3}\right)}{100} \\
& \mathrm{DC}=\left(\frac{\left(\mathrm{N}_{1}+\mathrm{N}_{2}+\mathrm{N}_{3}\right)}{100}\right) \times 100 \\
& \% \mathrm{R}=\frac{[\text { PC score mean }]-[\text { Treatment score mean }]}{[\text { PC score mean }- \text { NC score mean }]} \mathrm{X} 100
\end{aligned}
$$

\subsection{Reactive oxygen and nitrogen species (RONS)}

Intracellular reactive oxygen and nitrogen species were evaluated using the fluorescent probe CM- $\mathrm{H}_{2}$ DCFDA (Sigma-Aldrich). CM$\mathrm{H}_{2}$ DCFDA (5-(and-6)-chloromethyl-2',7'-dichlorodihydrofluorescein diacetate) passively diffuses into the cells in which it is easily oxidized by RONS and converted into highly fluorescent compounds (Lu and Finkel, 2008). The fluorescence intensity is directly proportional to the intracellular RONS generated. Hydrogen peroxide $\left(\mathrm{H}_{2} \mathrm{O}_{2}\right)$ was used to induce RONS and its concentration was previously established by means of a preliminary assay in which the Jurkat cells were exposed to increasing concentrations ranging from 25 to $200 \mu \mathrm{M}$.

The oxidation assay was conducted on both normal and Jurkat human lymphocytes assessing five concentrations of botryosphaeran $(7.5,15,30,60$ and $100 \mu \mathrm{g} / \mathrm{mL})$. Concentrations of 15 and $60 \mu \mathrm{g} / \mathrm{mL}$ were included because they were intermediate to those evaluated in the comet assay. Approximately $1 \times 10^{4}$ lymphocyte cells were incubated with botryosphaeran for 3, 9 and $24 \mathrm{~h}$ in 96-well microplates. Freshly made $\mathrm{H}_{2} \mathrm{O}_{2}$ (Sigma-Aldrich; $100 \mu \mathrm{M}$ ) solution in water was added to 
each well at the end of each treatment time. Exposure of the lymphocytes to $\mathrm{H}_{2} \mathrm{O}_{2}$ was for $1 \mathrm{~h}$ only. The positive control group consisted of $\mathrm{H}_{2} \mathrm{O}_{2}$-treated cells ( $\left.100 \mu \mathrm{M}\right)$, and the negative control group consisted of PBS-treated cells ( $\mathrm{pH} 7.4$ ). Subsequently, the cells in the microplate wells were centrifuged ( $300 \times \mathrm{g} / 5 \mathrm{~min})$, the supernatant was discarded, and $100 \mu \mathrm{L}$ of $\mathrm{CM}-\mathrm{H}_{2}$ DCFDA solution $(5 \mathrm{mM})$ was added to each well and incubated for $30 \mathrm{~min}$. Fluorescence analysis was performed in a fluorimeter (Biotek, Synergy ${ }^{\mathrm{TM}}$ H1 Multi-Mode Reader, Winooski, VT, EUA), at an excitation wavelength of $485 \mathrm{~nm}$ and emission at $528 \mathrm{~nm}$. All treatments were performed in quadruplicate. The results were expressed based upon the values obtained in cells treated with $\mathrm{H}_{2} \mathrm{O}_{2}$ alone.

\subsection{Ames test for mutagenicity}

The mutagenicity of botryosphaeran was evaluated by the Ames test (Salmonella/liver microsome) using the preincubation methodology according to Maron and Ames (1983). The incubation was conducted in the presence $(+S 9)$ and absence $(-S 9)$ of the 59 microsomal fraction, which consists of a homogenate derived from rat liver (Maron and Ames, 1983). The present study used Salmonella typhimurium strains: TA98, TA97a, TA100 and TA102, and were kindly provided by Dr. Bruce Ames, University of California, Berkeley, CA, USA.

The S. typhimurium strains were maintained frozen in Oxoid nutrient broth n. 2 (Oxoid Ltd., Basingstoke, UK; 2.25\%) and DMSO 10\% and inocula prepared from this, grown for $14 \mathrm{~h}$ at $37^{\circ} \mathrm{C}$ in Oxoid nutrient broth $\mathrm{n}$. 2 to obtain a cell density of $1-2 \times 10^{9}$ colony forming cells $/ \mathrm{mL}$. The metabolic activation mixture (S9) was purchased from Molecular Toxicology (Boone, NC, USA), and consisted of a lyophilized preparation comprizing 4\% S9 fraction; $1 \% 0.4 \mathrm{M} \mathrm{MgCl}_{2}, 1 \% 1.65 \mathrm{M} \mathrm{KCl} ; 0.5 \% 1 \mathrm{M}$ glucose-6-phosphate disodium salt, 4\% 0.1 M NADP, and 50\% 0.2 M sodium phosphate buffer ( $\mathrm{pH} 7.4$ ), and was dissolved in $39.5 \%$ sterile distilled water and prepared fresh before each assay.

In the mutagenicity tests, botryosphaeran solutions of final concentrations $75,150,300,450,600 \mu \mathrm{g} /$ plate was each separately added to $0.5 \mathrm{~mL}$ of $0.2 \mathrm{M}$ phosphate buffer ( $\mathrm{pH} 7.4$ ) for the - S9 assays, followed by the addition of $0.1 \mathrm{~mL}$ of the bacterial culture, and the mixtures incubated for $30 \mathrm{~min}$ at $37^{\circ} \mathrm{C}$. In the metabolic activation tests ( $\left.+\mathrm{S} 9\right), 0.5 \mathrm{~mL}$ of the $\mathrm{S} 9$ reagent replaced the phosphate buffer. After the incubation period, $2.0 \mathrm{~mL}$ of surface agar (top agar $-0.6 \%$ agar and $0.6 \% \mathrm{NaCl}$ ) containing traces of L-histidine $(0.05 \mathrm{mM})$ and D-biotin $(0.05 \mathrm{mM})$ was added to the bacterial culture-botryosphaeran mixture, and then poured onto a Petri-plate containing glucose minimal agar medium (GM agar). The plates were further incubated at $37^{\circ} \mathrm{C}$ for $48 \mathrm{~h}$, and His + revertant bacterial colonies scored manually. The compounds used as positive controls $(\mathrm{C}+)$ in the assays without metabolic activation (-S9) were 4nitro-o-phenylenediamine (Sigma-Aldrich; NPD, $10 \mu \mathrm{g} /$ plate) for $S$. typhimurium strains TA97 and TA98, sodium azide $(2.5 \mu \mathrm{g} /$ plate $)$ for strain TA100, and mitomycin C (Sigma-Aldrich; $0.5 \mu \mathrm{g} / \mathrm{plate}$ ) for the TA102 strain. Compounds used in the assays with metabolic activation (+S9) included: 2-antramine (Sigma-Aldrich; 2-ANTR, $1.25 \mu \mathrm{g} /$ plate) for the TA97, TA98 and TA100 strains, and 2-aminofluorene (10 $\mu \mathrm{g} /$ plate) for the TA102 strain. Negative controls were performed using the samples' solvent, i.e., sterile distilled water.

The mutagenicity index (MI) was calculated for each analyzed sample based on the results obtained according to the following formula (Maron and Ames, 1983).

$\mathrm{MI}=\frac{\text { Number of revertants in the plate with test compound }}{\text { Number of revertants in the plate with negative control }}$

\subsection{Statistical analysis}

All results were expressed as the mean \pm standard deviation. All the means from the tests with Jurkat cells were obtained from three independent experiments. Means derived from tests with normal lymphocytes were obtained from four different individuals donating the peripheral blood. Variance analysis (ANOVA) and Tukey test at 5\% significance level were used to analyze genotoxicity, antigenotoxicity and the reactive oxygen and nitrogen species data. These statistical analyses were performed using GraphPad INSTAT software, version 3.02 (http://www.graphpad.com/scientific-software/instat/). Mutagenicity data were analyzed by variance analysis (ANOVA) followed by the linear regression test at the 5\% significance level, and using Salanal statistical software (Environmental Protection Agency of the United States, Monitoring Systems Laboratory, Las Vegas, NV, version 1.0, Research Triangle Institute, RTP, NC, USA), according to the model by Bernstein et al. (Bernstein et al., 1982).

\section{Results}

\subsection{Genotoxicity and antigenotoxicity}

The results from normal and tumor lymphocytes treated with botryosphaeran, MMS, and a combination of both, are shown, respectively, in Tables 1 and 2 . The mutagenic agent MMS $(10 \mu \mathrm{M})$ was effective at causing damage to the DNA molecule. On the other hand, botryosphaeran showed no evidence of a genotoxic effect at any of the three concentrations tested in the different lymphocyte types under the conditions evaluated in the study.

The protective effect antigenotoxicity of botryosphaeran was observed in both normal and tumor lymphocytes (Tables 1 and 2). As for the normal lymphocytes, this protective effect was observed only in botryosphaeran in the post-treatment conditions in comparison to MMS. It was possible to verify that the two higher evaluated concentrations of botryosphaeran ( 30 and $100 \mu \mathrm{g} / \mathrm{mL}$ ) led to protective effects of $72.41 \%$ and $91.09 \%$, respectively.

As for the tumor cells, this protective effect was observed in both associated protocols. In the simultaneous treatment, botryosphaeran at concentrations of 30 and $100 \mu \mathrm{g} / \mathrm{mL}$ showed $60.71 \%$ and $63.39 \%$ reduction of DNA damage, respectively, while the post-treatment condition using 30 and $100 \mu \mathrm{g}$ botryosphaeran $/ \mathrm{mL}$ resulted in a reduction of damage to DNA of $64.52 \%$ and $61.29 \%$, respectively (Table 2).

\subsection{Reactive oxygen and nitrogen species}

Jurkat cells were exposed to increasing hydrogen peroxide concentrations (from 25 to $200 \mu \mathrm{M}$ ) in order to assess intracellular production of RONS and to set the limits of concentration that are able to significantly promote the release of RONS within these cells. Fig. 1 shows that all concentrations of $\mathrm{H}_{2} \mathrm{O}_{2}$ were equally efficient in generating RONS. Thus, in the experiments of the present study, a $\mathrm{H}_{2} \mathrm{O}_{2}$ concentration of $100 \mu \mathrm{M}$ was used, as was also reported by Serpeloni et al. (2012).

Results obtained for normal and tumor lymphocyte cell cultures treated with different concentrations of botryosphaeran in combination with $100 \mu \mathrm{M} \mathrm{H}_{2} \mathrm{O}_{2}$ are shown in Fig. 2. Fig. $2 \mathrm{~A}, \mathrm{~B}$ and $\mathrm{C}$ shows the results from the RONS generated in the Jurkat cells subjected to treatment with botryosphaeran at concentrations of 7.5, 15, 30, 60 and $100 \mu \mathrm{g} / \mathrm{mL}$ for 3 , 9 and $24 \mathrm{~h}$ in combination with $100 \mu \mathrm{M} \mathrm{H}_{2} \mathrm{O}_{2}$. Data analyses showed that all of the tested concentrations did not decrease the formation of $\mathrm{H}_{2} \mathrm{O}_{2}$-induced RONS for the different times of treatment.

Reactive oxygen and nitrogen species generation in normal human lymphocytes subjected to the same treatments showed similar results to those found for the Jurkat cells. There was significant $\mathrm{H}_{2} \mathrm{O}_{2}$-induced RONS production by the normal lymphocytes with time, and botryosphaeran did not offer protection to these cells under the conditions evaluated (Fig. 2D, E and F). 
Table 1

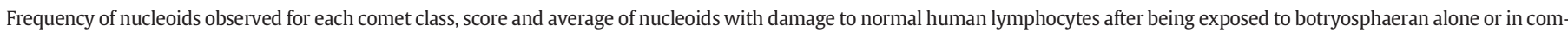
bination with methyl methanesulfonate (MMS) in simultaneous treatment (SIM) and in post-treatment (POST).

\begin{tabular}{|c|c|c|c|c|c|c|c|c|}
\hline & & \multicolumn{4}{|c|}{ Comet classes (100 cells/experiment) } & \multirow[b]{2}{*}{ Score $(X \pm S D)$} & \multirow[b]{2}{*}{ DNA damage $(\mathrm{X} \pm \mathrm{SD})$} & \multirow[t]{2}{*}{ \% Reduction } \\
\hline \multicolumn{2}{|c|}{ Treatments $(\mu \mathrm{g} / \mathrm{mL})$} & 0 & 1 & 2 & 3 & & & \\
\hline \multicolumn{2}{|l|}{ PBS } & $85.00 \pm 7.00$ & $6.67 \pm 2.89$ & $6.67 \pm 2.08$ & $2.33 \pm 3.21$ & $21.0 \pm 16.64^{\mathrm{b}}$ & $0.13 \pm 0.08^{\mathrm{b}}$ & - \\
\hline \multirow[t]{3}{*}{ EPS } & 7.5 & $79.33 \pm 8.50$ & $12.67 \pm 5.51$ & $5.00 \pm 0.00$ & $1.67 \pm 1.53$ & $27.67 \pm 10.07$ & $0.19 \pm 0.07$ & - \\
\hline & 30 & $73.33 \pm 15.28$ & $12.00 \pm 10.54$ & $7.67 .3 \pm 5.51$ & $2.00 \pm 1.73$ & $33.33 \pm 22.30$ & $0.22 \pm 0.16$ & - \\
\hline & 100 & $79.00 \pm 13.89$ & $13.00 \pm 13.86$ & $4.33 \pm 0.58$ & $3.00 \pm 1.73$ & $30.67 \pm 13.20$ & $0.20 \pm 0.14$ & - \\
\hline MMS $^{1}$ & $10 \mu \mathrm{M}$ & $2.33 \pm 1.53$ & $10.33 \pm 7.57$ & $23.00 \pm 8.89$ & $65.00 \pm 2.65$ & $251.33 \pm 5.51^{\mathrm{a}}$ & $0.98 \pm 0.01^{\mathrm{a}}$ & - \\
\hline \multirow{3}{*}{ SIM } & MMS + 7.5 & $7.00 \pm 4.58$ & $22.00 \pm 5.20$ & $20.00 \pm 1.73$ & $54.67 \pm 8.7$ & $226.00 \pm 24.06^{\mathrm{a}}$ & $0.97 \pm 0.05^{\mathrm{a}}$ & - \\
\hline & MMS + 30 & $3.33 \pm 4.93$ & $24.33 \pm 4.16$ & $30.67 \pm 4.04$ & $42.00 \pm 6.56$ & $211.67 \pm 14.57^{\mathrm{a}}$ & $0.97 \pm 0.05^{\mathrm{a}}$ & - \\
\hline & MMS + 100 & $14.00 \pm 12.77$ & $21.67 \pm 4.51$ & $22.00 \pm 4.36$ & $41.00 \pm 12.53$ & $188.67 \pm 44.12^{\mathrm{a}}$ & $0.85 \pm 0.16^{\mathrm{a}}$ & - \\
\hline $\mathrm{MMS}^{2}$ & $10 \mu \mathrm{M}$ & $36.67 \pm 13.01$ & $15.0 \pm 11.53$ & $11.00 \pm 8.66$ & $33.33 \pm 8.50$ & $137.00 \pm 27.40^{\mathrm{a}}$ & $0.59 \pm 0.14^{\mathrm{a}}$ & - \\
\hline \multirow[t]{3}{*}{ POST } & MMS + 7.5 & $38.33 \pm 5.51$ & $28.67 \pm 2.52$ & $11.33 \pm 1.53$ & $21.67 \pm 4.51$ & $116.33 \pm 15.63^{\mathrm{a}}$ & $0.62 \pm 0.06^{\mathrm{a}}$ & - \\
\hline & MMS + 30 & $70.67 \pm 16.26$ & $13.33 \pm 10.41$ & $8.33 \pm 3.21$ & $7.67 \pm 3.21$ & $53.00 \pm 25.06^{\mathrm{b}}$ & $0.29 \pm 0.16^{\mathrm{b}}$ & $72.41^{\mathrm{b}}$ \\
\hline & MMS + 100 & $85.67 \pm 2.08$ & $4.00 \pm 3.00$ & $3.67 \pm 1.53$ & $6.67 \pm 1.15$ & $31.33 \pm 4.04^{\mathrm{b}}$ & $0.14 \pm 0.02^{\mathrm{b}}$ & $91.09^{b}$ \\
\hline
\end{tabular}

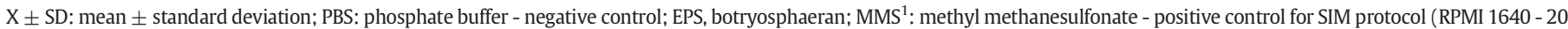

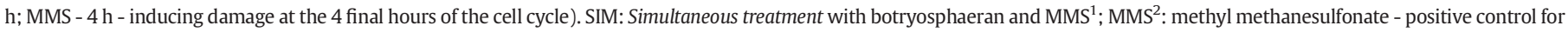
POST protocol (RPMI 1640 - 20 h; MMS-4 h-inducing damage at the 4 initial hours of the cell cycle); POST: cells treated with botryosphaeran after MMS ${ }^{2}$.

a Statistically different values of the negative control (PBS) at $5 \%$ by ANOVA followed by the Tukey test.

b Statistically different values of the positive control $\left(\mathrm{MMS}^{1}\right.$ or $\left.\mathrm{MMS}^{2}\right)$ at $5 \%$ by ANOVA followed by the Tukey test.

\subsection{Ames test}

Table 3 shows the mean number of bacterial revertants per plate, the standard deviation (SD) and mutagenicity index (MI) observed after the treatment of four different S. typhimurium strains (TA98, TA100, TA102 and TA97) with five different concentrations of botryosphaeran (75, $150,300,450$, and $600 \mu \mathrm{g} / \mathrm{mL}$ ) in the presence $(+\mathrm{S} 9)$ and absence (-S9) of metabolic activation. The mutagenicity tests demonstrated that botryosphaeran did not induce any significant increase in the number of revertant colonies in any of the treatments evaluated in the different bacterial strains used in the Ames test. Furthermore, there were no significant differences in the results with and without metabolic activation.

\section{Discussion}

$\beta$-D-Glucans of the $(1 \rightarrow 3)-,(1 \rightarrow 3)(1 \rightarrow 6)$ - and $(1 \rightarrow 6)$-linked types such as produced by certain bacterial, yeast and fungal species and strains have been the subject of intense investigation because of their biological response modifying (BRM) activities in the host, and this attribute favors their application in medical therapy (Chen and
Seviour, 2007; Williams, 2009). Identifying and studying the biological effects of macromolecules that include polysaccharides and polysaccharide-protein complexes, have helped in introducing effective cancer therapeutic agents onto the pharmaceutical market (Zong et al., 2012). Although much of the literature associated with these biopolymers is of a protective nature, and usually bears little or no toxic activity, there are literature reports involving the mutagenic potential of molecules found in fungal extracts that may contain biopolymers (Sugimura, 2000), e.g., agaritine from Agaricus bisporus (Pool-Zobel et al., 1990), and the carcinogenic, mutagenic and teratogenic activities of 11 compounds derived from 22 mushrooms species (Toth, 1991).

The guidelines of the Organization for Economic Cooperation and Development (OECD) used to identify and characterise potential hazards of chemicals including mutagens recommends two in vitro tests that should be conducted to assess chromosomal damage: the reverse mutation (Ames) test using bacteria to assess point mutation (OECD, 1997), and the micronucleus test on mammalian cells (ICH guidance S2(R1) OECD, 2014). In addition, because of its sensitive nature, the Comet test (Di Sotto et al., 2014) should also be considered as this evaluates genotoxicity of chemical compounds revealing very early damage to DNA (Collins, 2014; Kimura et al., 2013) and its universal applicability to all kinds of cells (Cortés-Gutiérrez et al., 2011). Once the absence of

Table 2

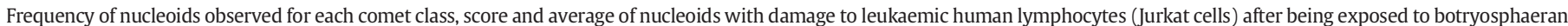
alone, or in combination with methyl methanesulfonate (MMS) in simultaneous treatment (SIM) and in post-treatment (POST).

\begin{tabular}{|c|c|c|c|c|c|c|c|c|}
\hline \multirow{2}{*}{\multicolumn{2}{|c|}{ Treatments $(\mu \mathrm{g} / \mathrm{mL})$}} & \multicolumn{4}{|c|}{ Comet classes (100 cells/experiment) } & \multirow[b]{2}{*}{ Score $(X \pm S D)$} & \multirow[b]{2}{*}{ DNA damage $(\mathrm{X} \pm \mathrm{SD})$} & \multirow[b]{2}{*}{ \% Reduction } \\
\hline & & 0 & 1 & 2 & 3 & & & \\
\hline PBS & & $96.00 \pm 3.61$ & $4.00 \pm 3.61$ & $0.00 \pm 0.00$ & $0.00 \pm 0.00$ & $4.00 \pm 3.61^{\mathrm{b}}$ & $0.04 \pm 0.04^{\mathrm{b}}$ & - \\
\hline \multirow[t]{3}{*}{ EPS } & 7.5 & $97.00 \pm 2.00$ & $2.33 \pm 1.53$ & $0.67 \pm 0.58$ & $0.00 \pm 0.00$ & $3.67 \pm 2.52$ & $0.03 \pm 0.02$ & - \\
\hline & 30 & $95.67 \pm 2.08$ & $3.00 \pm 1.00$ & $1.33 \pm 1.15$ & $0.00 \pm 0.00$ & $5.67 \pm 3.21$ & $0.04 \pm 0.02$ & - \\
\hline & 100 & $98.33 \pm 2.89$ & $1.33 \pm 2.31$ & $0.33 \pm 0.58$ & $0.00 \pm 0.00$ & $2.00 \pm 3.46$ & $0.02 \pm 0.03$ & - \\
\hline MMS $^{1}$ & $10 \mu \mathrm{M}$ & $4.33 \pm 2.08$ & $55.33 \pm 12.50$ & $32.00 \pm 17.78$ & $11.33 \pm 4.04$ & $153.33 \pm 15.18^{a}$ & $0.99 \pm 0.06^{\mathrm{a}}$ & - \\
\hline \multirow[t]{3}{*}{ SIM } & MMS + 7.5 & $0.00 \pm 0.00$ & $88.00 \pm 5.57$ & $11.67 \pm 4.04$ & $0.67 \pm 1.15$ & $113.33 \pm 5.86^{a, b}$ & $1.00 \pm 0.01^{\mathrm{a}}$ & - \\
\hline & MMS + 30 & $38.00 \pm 3.00$ & $55.33 \pm 6.66$ & $3.67 \pm 2.89$ & $0.00 \pm 0.00$ & $62.67 \pm 6.66^{\mathrm{a}, \mathrm{b}}$ & $0.59 \pm 0.06^{\mathrm{a}, \mathrm{b}}$ & $60.71^{\mathrm{b}}$ \\
\hline & MMS + 100 & $43.00 \pm 4.00$ & $56.00 \pm 2.65$ & $1.33 \pm 1.15$ & $0.00 \pm 0.00$ & $58.67 \pm 4.51^{\mathrm{a}, \mathrm{b}}$ & $0.57 \pm 0.04^{\mathrm{a}, \mathrm{b}}$ & $63.39^{\mathrm{b}}$ \\
\hline $\mathrm{MMS}^{2}$ & $10 \mu \mathrm{M}$ & $85.67 \pm 1.53$ & $8.33 \pm 1.53$ & $1.67 \pm 1.53$ & $4.33 \pm 2.31$ & $24.67 \pm 3.51^{\mathrm{a}}$ & $0.14 \pm 0.02^{\mathrm{a}}$ & - \\
\hline \multirow[t]{3}{*}{ POST } & MMS + 7.5 & $88.33 \pm 3.06$ & $7.33 \pm 3.51$ & $2.67 \pm 1.53$ & $1.67 \pm 1.53$ & $17.67 \pm 1.53^{\mathrm{a}}$ & $0.12 \pm 0.03^{\mathrm{a}}$ & - \\
\hline & MMS +30 & $89.67 \pm 2.52$ & $9.33 \pm 3.06$ & $1.00 \pm 1.00$ & $0.00 \pm 0.00$ & $11.33 \pm 2.31^{\mathrm{a}, \mathrm{b}}$ & $0.10 \pm 0.03$ & $64.52^{\mathrm{b}}$ \\
\hline & MMS + 100 & $92.00 \pm 2.00$ & $7.00 \pm 2.65$ & $0.00 \pm 0.00$ & $1.67 \pm 1.53$ & $12.00 \pm 2.00^{\mathrm{a}, \mathrm{b}}$ & $0.09 \pm 0.01$ & $61.29^{b}$ \\
\hline
\end{tabular}

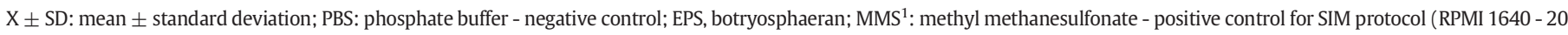

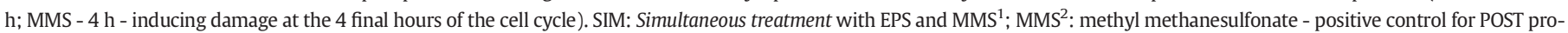
tocol (RPMI 1640 - 20 h; MMS-4 h-inducing damage at the 4 initial hours of the cell cycle); POST: cells treatment with EPS after MMS ${ }^{2}$.

a Statistically different values of the negative control (PBS) at $5 \%$ level by ANOVA followed by Tukey test.

b Statistically different values of the positive control $\left(\mathrm{MMS}^{1}\right.$ or $\mathrm{MMS}^{2}$ ) at $5 \%$ level by ANOVA followed by Tukey test. 


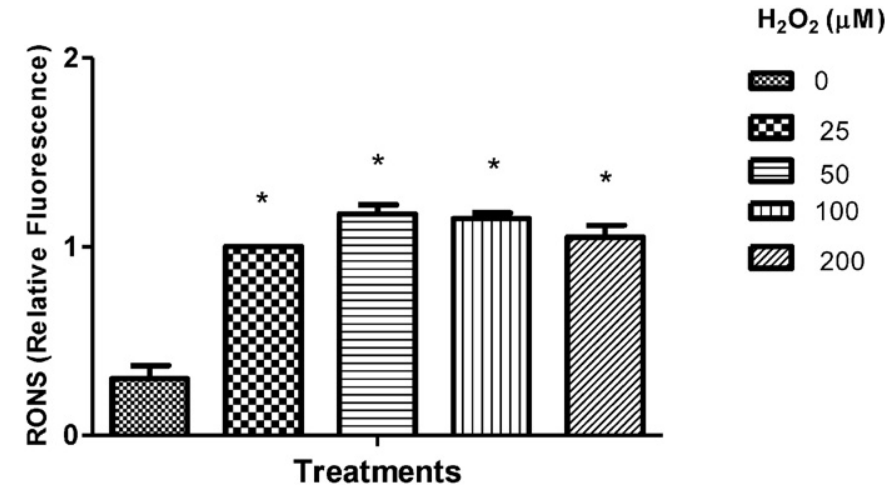

Fig. 1. Reactive oxygen and nitrogen species (RONS) production (in relative fluorescence units) in Jurkat cells exposed to different concentrations of $\mathrm{H}_{2} \mathrm{O}_{2}$ and their respective control. *Different values from the negative control $(0 \mu \mathrm{M})$ at $5 \%$ level by ANOVA analysis followed by Tukey test.

genotoxicity in a chemical agent has been verified, it can be evaluated for its protective potential against DNA damage.

The investigation reported herein on the in vitro genotoxic and mutagenic studies on normal and tumor human T lymphocyte cultures, and on S. typhimurium strains, by the exopolysaccharide botryosphaeran, a $(1 \rightarrow 3)(1 \rightarrow 6)-\beta$-D-glucan, was expanded to include the Ames test and Comet assay, and further advances the knowledge acquired from our earlier studies on the in vivo genotoxic approach reported by Miranda et al. (2008). These tests are important in validating the biosafety of botryosphaeran.

Bacterial mutagenicity tests are used worldwide as part of the selection strategy in investigating the safety of chemical compounds by the pharmaceutical industry during drug testing. The mutagenicity index of the five botryosphaeran concentrations evaluated in the Ames test was less than twice of that observed in the negative control group. From this result, we infer that botryosphaeran does not pose a mutagenic hazard in the presence or absence of the S9 fraction, under the conditions evaluated in the Ames test experiments.

The negative data regarding botryosphaeran genotoxicity and mutagenicity obtained in the present study corroborates the results obtained by our research group from the in vivo micronucleus tests conducted on mice (Miranda et al., 2008), as well as other still unpublished data (in vitro micronucleus test and comet assay with the mammalian cell lines, V79 and HTC). The association between the reverse mutation test and the micronucleus test appeared to be effective to evaluate the genotoxic potential of new therapeutic agents. Thus, when the results from both tests are negative, additional genotoxic tests are not necessary (Kirkland et al., 2011). Therefore, it is possible to consider botryosphaeran as a low mutagenic and genotoxic biomacromolecule; a fact that will assist the validation process as a therapeutic agent.

Given the potential of non-cellulosic $\beta$-glucans modifying host biological responses, antigenotoxic tests were performed on normal and tumoral human $\mathrm{T}$ lymphocyte cultures to confirm the protective action of botryosphaeran against the damage induced by the alkylating agent, methyl methanesulfonate. Our results indicate that treatment with botryosphaeran was able to exert a protective action on the normal and tumor lymphocyte cells evaluated, and this was more efficient on normal lymphocytes under the post-treatment condition assessed. Moreover, the $72.4 \%$ and $91.1 \%$ reduction in MMS-induced damage in normal human lymphocytes treated, respectively, with 30 and $100 \mu \mathrm{g} /$ $\mathrm{mL}$ of botryosphaeran under both the simultaneous treatment and post-treatment, suggests the potential of this compound as a bioagent that possibly acts on the repair mechanism of DNA leading to decreasing mutations. This activity was reported by Kada and Shimoi (1987) as bioantimutagenic activity. This kind of cell signal modulation mechanism is possibly triggered by botryosphaeran binding to specific cell membrane receptors, such as CR3-1 and dectin-1 receptors. These receptors have been described as being able to interact with $\beta$-glucans (Williams, 2009). Nevertheless, data recently published by our research group (Malini et al., 2015), on gene expression analysis of some $\beta$-glucan pattern recognition cell receptors, indicated no interference by botryosphaeran in the expression of genes encoding CR3 and dectin-1

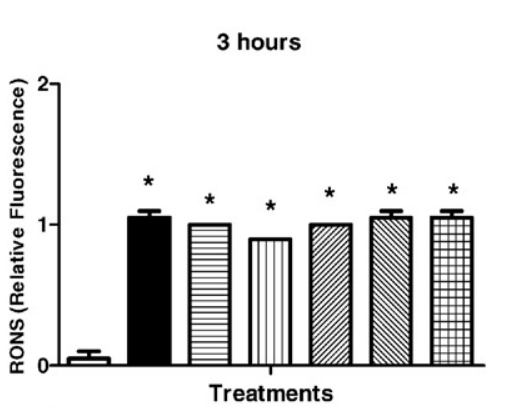

A

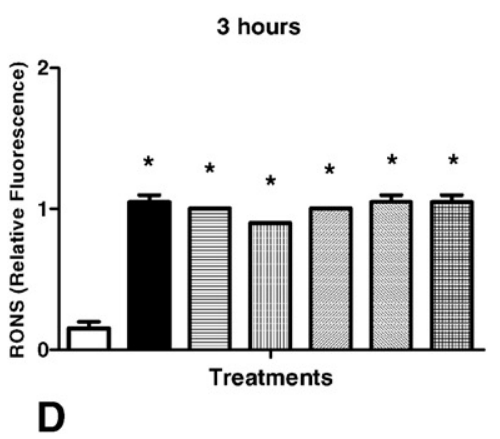

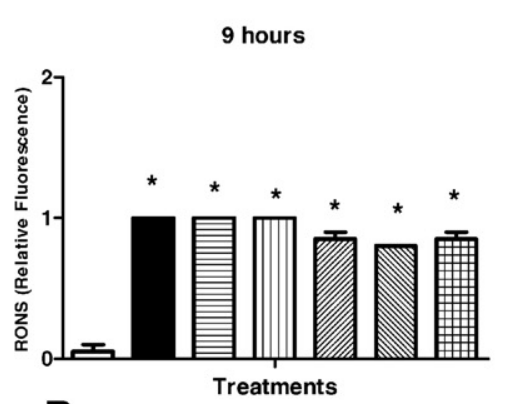

B

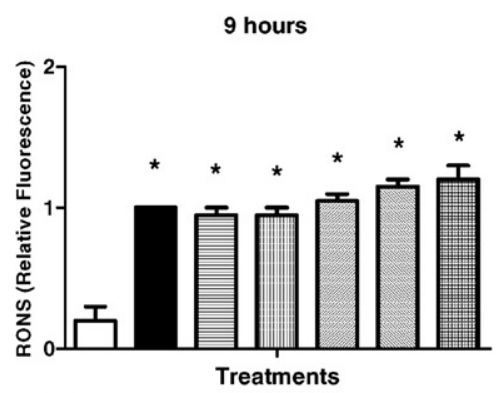

E

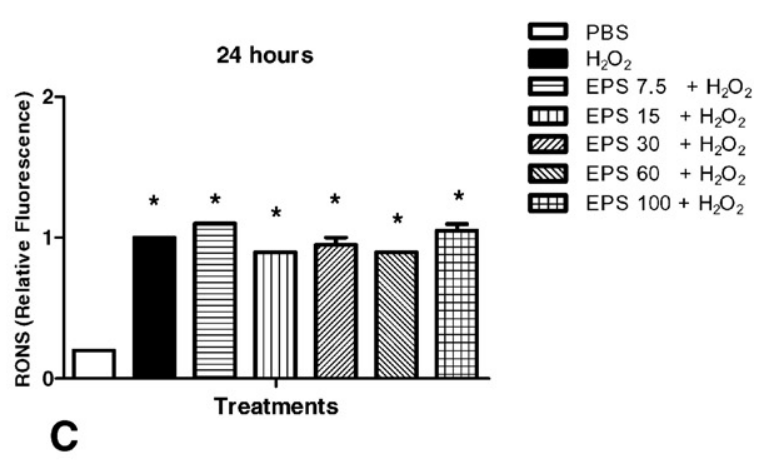

24 hours

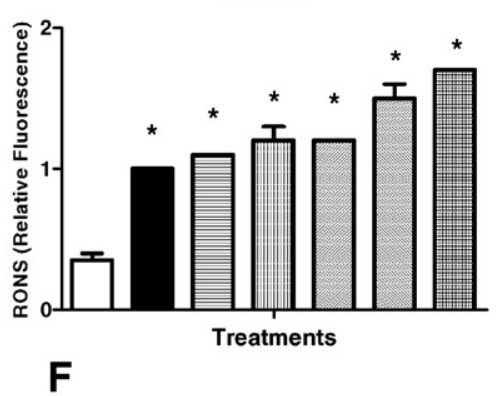

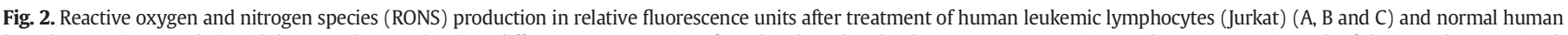

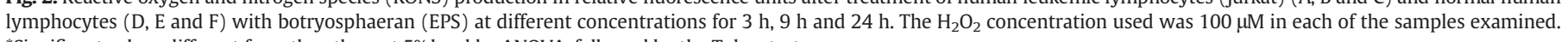
*Significant values different from the others at $5 \%$ level by ANOVA, followed by the Tukey test. 
Table 3

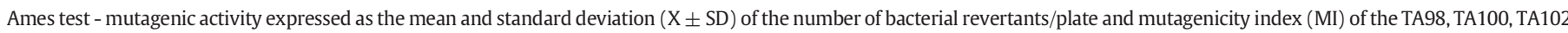
and TA97 Salmonella typhimurium strains exposed to five different concentrations of botryosphaeran with (+S9) and without (-S9) metabolic activation.

\begin{tabular}{|c|c|c|c|c|c|c|c|c|}
\hline \multirow{3}{*}{ Treatment ( $\mu \mathrm{g} /$ plate) } & \multicolumn{8}{|c|}{ Number of revertants/plate $(\mathrm{X} \pm \mathrm{SD})$ and mutagenicity index (MI, values in parenthesis) Salmonella typhimurium strains } \\
\hline & \multicolumn{2}{|l|}{ TA 98} & \multicolumn{2}{|l|}{ TA 100} & \multicolumn{2}{|l|}{ TA 102} & \multicolumn{2}{|l|}{ TA 97a } \\
\hline & -S9 & +S9 & -S9 & +S9 & $-S 9$ & + S9 & - S9 & +S9 \\
\hline $0.00^{\mathrm{a}}$ & $29 \pm 2$ & $24 \pm 2$ & $120 \pm 6$ & $90 \pm 4$ & $576 \pm 13$ & $599 \pm 2$ & $133 \pm 21$ & $119 \pm 11$ \\
\hline 75 & $33 \pm 2(1.1)$ & $29 \pm 2(1.2)$ & $126 \pm 1(1.0)$ & $112 \pm 27(1.2)$ & $577 \pm 23(1.0)$ & $575 \pm 16(1.0)$ & $125 \pm 11(0.9)$ & $126 \pm 8(1.1)$ \\
\hline 150 & $25 \pm 1(0.9)$ & $25 \pm 3(1.1)$ & $107 \pm 3(0.9)$ & $90 \pm 15(1.0)$ & $555 \pm 27(1.0)$ & $604 \pm 17(1.0)$ & $134 \pm 4(0.9)$ & $136 \pm 9(1.1)$ \\
\hline 300 & $25 \pm 1(0.9)$ & $27 \pm 6(1.1)$ & $130 \pm 9(1.1)$ & $91 \pm 4(1.0)$ & $554 \pm 8(1.0)$ & $600 \pm 11(1.0)$ & $133 \pm 5(1.1)$ & $133 \pm 8(1.1)$ \\
\hline 450 & $26 \pm 2(0.9)$ & $31 \pm 2(1.3)$ & $120 \pm 3(1.0)$ & $97 \pm 11(1.1)$ & $575 \pm 6(1.0)$ & $627 \pm 20(1.0)$ & $154 \pm 21(1.2)$ & $123 \pm 2(1.0)$ \\
\hline 600 & $28 \pm 3(1.0)$ & $34 \pm 4(1.4)$ & $114 \pm 2(1.0)$ & $89 \pm 11(1.0)$ & $541 \pm 6(0.9)$ & $654 \pm 11(1.1)$ & $139 \pm 8(1.0)$ & $115 \pm 11(1.0)^{g}$ \\
\hline $\mathrm{C}+$ & $1455 \pm 5^{\mathrm{b}}$ & $292 \pm 7^{e}$ & $2715 \pm 54^{c}$ & $484 \pm 9^{\mathrm{e}}$ & $2171 \pm 59^{d}$ & $702 \pm 6^{\mathrm{f}}$ & $1364 \pm 4^{\mathrm{b}}$ & $569 \pm 25^{\mathrm{e}}$ \\
\hline
\end{tabular}

a Negative Control: Milli-Q water (200 $\mu \mathrm{L} /$ plate); C .

b Positive Controls: 4-nitro-o-phenylenediamine (NPD - $10.0 \mu \mathrm{g} /$ plate).

c Sodium azide $(1.25 \mathrm{~g} /$ plate $)$.

d Mitomycin C ( $0.5 \mathrm{~g} /$ plate).

e 2-Antramine ( $1.25 \mathrm{~g} / \mathrm{plate})$.

f 2-Aminofluorene ( $10.0 \mathrm{~g} /$ plate).

g Different values from the others at $5 \%$ level by ANOVA analysis followed by the linear regression test at the $5 \%$ significance level.

receptors. On the other hand, repression was observed in the CCR5 gene transcripts when normal lymphocyte cells were treated with botryosphaeran alone, and in association with doxorubicin (DXR). This may indicate a possible mechanism of molecular action of botryosphaeran. It is likely that this $\beta$-glucan has binding affinity for the CCR5 receptor, thus inhibiting its gene product (Malini et al., 2015). According to Weitzenfeld and Ben-Baruch (2014), high CCR5 gene expression is associated with pro-malignancy and tumor growth. Since DXR and MMS are agents that cause distinct damage in cells, the development of protective effects against MMS-induced damage in normal lymphocytes as well as the antitumor effect observed on Jurkat cells treated with DXR and in combination with botryosphaeran (Malini et al., 2015) - both under post-treatment conditions - demonstrated that botryosphaeran has the ability to exercise different forms of protection.

The antitumor activity of $\beta$-glucans may also be influenced by their antioxidant capacity; i.e., oxidative stress. A study conducted on the free radical scavenging ability of botryosphaeran in an in vitro model was evaluated in the absence of mammalian cells and demonstrated total antioxidant activity (80\%), as well as scavenging of hydroxyl radicals (90.6\%) and nitric oxide (90\%) (Giese et al., 2015). Botryosphaeran investigated in our study showed no antioxidant effect on normal and tumor lymphocytes treated with $\mathrm{H}_{2} \mathrm{O}_{2}$ under any of the concentrations evaluated. Thus, the present study did not corroborate the data gathered by Giese et al. (2015) who found antioxidative capacity in botryosphaeran in comparison to $\mathrm{H}_{2} \mathrm{O}_{2}$ (38\%).

The lack of antioxidant activity in the lymphocyte cells studied in the present study may have been due to the low botryosphaeran concentrations in the co-treatment evaluated, and the short duration times (3, 9 and $24 \mathrm{~h}$ ), in comparison to that in studies by Giese et al. (2015) who found more relevant activity at $3 \mathrm{~g} / \mathrm{L}$ concentration. Although chemical in vitro tests are widely accepted in antioxidant evaluations, they are not representative of human cell conditions (Fukumoto and Mazza, 2000; Peris et al., 1997).

\section{Conclusion}

This study revealed that botryosphaeran was not mutagenic and genotoxic in normal and tumor human $\mathrm{T}$ lymphocytes as evaluated by the Ames and Comet assays, respectively. This carbohydrate biomacromolecule exhibited antigenotoxic activity against damage induced by the alkylating agent MMS in normal and tumorigenic lymphocytes. Although there are reports in the literature on the antioxidant capacity of fungal exopolysaccharides, botryosphaeran did not appear to reduce $\mathrm{H}_{2} \mathrm{O}_{2}$-induced RONS production in the human lymphocyte cells studied herein. The findings of this study reinforce the absence of genotoxic effects of botryosphaeran and helps validating the use of this $\beta$-glucan for commercial applications. Moreover, the findings reported here will encourage further investigations to foster a better understanding of the protective mechanisms of botryosphaeran as triggered in human lymphocytes following their exposure to alkylating agents.

\section{Transparency document}

The Transparency document associated with this article can be found, in the online version.

\section{Acknowledgements}

This study was primarily supported by a grant from Conselho Nacional de Desenvolvimento Científico e Tecnológico (CNPq - Process n. 478839/2012-0). The Natural Science and Engineering Research Council of Canada (NSERC) is acknowledged for a Research Capacity Development grant awarded by Lakehead University to R.F.H. Dekker. The authors thank CAPES for a doctorate scholarship to M. Malini, and CNPq for the research grant awarded to I.M.S. Colus and to L.M.G. Antunes. We also thank the volunteers who donated blood, and Rossana Batista de Oliveira Godoy Camargo, Jefferson Codognotto, Regislaine Valeria Burim, Fabiana Lima da Silva and Dario Tormena for technical assistance.

\section{References}

Barbosa, A.M., Steluti, R.M., Dekker, R.F.H., Cardoso, M.S., Corradi da Silva, M.L., 2003. Structural characterization of Botryosphaeran: a $(1 \rightarrow 3 ; 1 \rightarrow 6)-\beta$-D-glucan produced by the ascomyceteous fungus, Botryosphaeria sp. Carbohydr. Res. 338, 1691-1698.

Bernstein, L., Kaldor, J., McCann, J., Pike, M.C., 1982. An empirical approach to the statistical analysis of mutagenesis data from the Salmonella test. Mutat. Res./Environ. Mutagen. Relat. Subj. 97, 267-281.

Bohn, J.A., BeMiller, J.N., 1995. ( $1 \rightarrow 3$ )-B-D-Glucans as biological response modifiers: a review of structure-functional activity relationships. Carbohydr. Polym. 28, 3-14.

Brandi, J., Oliveira, E.C., Monteiro, N.K., Vasconcelos, A.F.D., Dekker, R.F.H., Barbosa, A.M., Silveira, J.L.M., Mourão, P.A.S., Corradi da Silva, M.d.L., 2011. Chemical modification of botryosphaeran: structural characterization and anticoagulant activity of a water-soluble sulfonated $(1 \rightarrow 3)(1 \rightarrow 6)-\beta$-D-glucan. J. Microbiol. Biotechnol. 21, 1036-1042.

Chen, J., Seviour, R., 2007. Medicinal importance of fungal beta- $(1 \rightarrow 3),(1 \rightarrow 6)$-glucans. Mycol. Res. 111, 635-652.

Collins, A.R., 2014. Measuring oxidative damage to DNA and its repair with the comet assay. Biochim. Biophys. Acta Gen. Subj. 1840, 794-800.

Cortés-Gutiérrez, E.I., Dávila-Rodríguez, M.I., Fernández, J.L., López-Fernández, C., Gosálbez, A., Gosálvez, J., 2011. New application of the comet assay: chromosomecomet assay. J. Histochem. Cytochem. 59, 655-660.

Di Sotto, A., Maffei, F., Hrelia, P., Di Giacomo, S., Pagano, E., Borrelli, F., Mazzanti, G., 2014 Genotoxicity assessment of some cosmetic and food additives. Regul. Toxicol. Pharmacol. 68, 16-22.

Fukumoto, L.R., Mazza, G., 2000. Assessing antioxidant and prooxidant activities of phenolic compounds†. J. Agric. Food Chem. 48, 3597-3604. 
Giese, E.C., Gascon, J., Anzelmo, G., Barbosa, A.M., da Cunha, M.A.A., Dekker, R.F.H., 2015 Free-radical scavenging properties and antioxidant activities of botryosphaeran and some other $\beta$-D-glucans. Int. J. Biol. Macromol. 72, 125-130

International Conference on Harmonisation. Guidance on S2(R1) Genotoxicity Testing and Data Interpretation for Pharmaceuticals intended for Human Use, 2012R. Food and Drug Administration, HHS. Fed. Regist. 77 (110), 33748-33749.

Kada, T., Shimoi, K., 1987. Desmutagens and bio-antimutagens - their modes of action. BioEssays 7, 113-116.

Kagimura, F.Y., da Cunha, M.A.A., Barbosa, A.M., Dekker, R.F.H., Malfatti, C.R.M., 2015. Biological activities of derivatized D-glucans: a review. Int. J. Biol. Macromol. 72 588-598.

Kimura, A., Miyata, A., Honma, M., 2013. A combination of in vitro comet assay and micronucleus test using human lymphoblastoid TK6 cells. Mutagenesis 28, 583-590.

Kirkland, D., Reeve, L., Gatehouse, D., Vanparys, P., 2011. A core in vitro genotoxicity battery comprising the Ames test plus the in vitro micronucleus test is sufficient to detect rodent carcinogens and in vivo genotoxins. Mutat. Res./Genet. Toxicol. Environ. Mutagen. 721, 27-73.

Kobayashi, H., Sugiyama, C., Morikawa, Y., Hayashi, M., Sofuni, T., 1995. A comparison between manual microscopic analysis and computerized image analysis in the single cell gel electrophoresis assay. MMS Commun. 3, 103-115.

Liang, J., Melican, D., Cafro, L., Palace, G., Fisette, L., Armstrong, R., Patchen, M.L., 1998. Enhanced clearance of a multiple antibiotic resistant Staphylococcus aureus in rats treated with PGG-glucan is associated with increased leukocyte counts and increased neutrophil oxidative burst activity. Int. J. Immunopharmacol. 20, 595-614.

Lu, T., Finkel, T., 2008. Free radicals and senescence. Exp. Cell Res. 314, 1918-1922.

Malini, M., Souza, M.F., Oliveira, M.T., Antunes, L.M.G., Figueiredo, S.G., Barbosa, A.M. Dekker, R.F.H., Cólus, I.M.S., 2015. Modulation of gene expression and cell cycle by botryosphaeran, a $(1 \rightarrow 3)(1 \rightarrow 6)-\beta-D-$ glucan in human lymphocytes. Int. J. Biol. Macromol. 77, 214-221.

Manoharan, K., Banerjee, M.R., 1985. $\beta$-Carotene reduces sister chromatid exchanges induced by chemical carcinogens in mouse mammary cells in organ culture. Cell Biol. Int. Rep. 9, 783-789.

Maron, D.M., Ames, B.N., 1983. Revised methods for the Salmonella mutagenicity test. Mutat. Res./Environ. Mutagen. Relat. Subj. 113, 173-215.

Miranda, C.C.B.O., Dekker, R.F.H., Serpeloni, J.M., Fonseca, E.A.I., Cólus, I.M.S., Barbosa, A.M., 2008. Anticlastogenic activity exhibited by botryosphaeran, a new exopolysaccharide produced by Botryosphaeria rhodina MAMB-05. Int. J. Biol. Macromol. 42, 172-177.

Miranda-Nantes, C.C.B.O., Fonseca, E.A.I., Zaia, C.T.B.V., Dekker, R.F.H., Khaper, N., Castro, I.A., Barbosa, A.M., 2011. Hypoglycemic and hypocholesterolemic effects of botryosphaeran from Botryosphaeria rhodina MAMB-05 in diabetes-induced and hyperlipidemia conditions in rats. Mycobiology 39, 187-193.

Miura, N.N., Ohno, N., Aketagawa, J., Tamura, H., Tanaka, S., Yadomae, T., 1996. Blood clearance of $(1 \rightarrow 3)-\beta$-D-glucan in MRL lpr/lpr mice. FEMS Immunol. Med. Microbiol. $13,51-57$.

Mosmann, T., 1983. Rapid colorimetric assay for cellular growth and survival: application to proliferation and cytotoxicity assays. J. Immunol. Methods 65, 55-63.

OECD, 1997. Test No. 471: Bacterial Reverse Mutation Test. OECD Publishing

OECD, 2014. Test No. 487: In Vitro Mammalian Cell Micronucleus Test. OECD Publishing.
Peris, F., Saco, Y., Gafo, C., Bassols, A., 1997. Comparison of two commercial kits for the enzymatic determination of nonesterified fatty acids in goat serum. Small Rumin. Res. 26, 181-187.

Pool-Zobel, B.L., Schmezer, P., Sinrachatanant, Y., Kliagasioglu, F., Reinhart, K., Martin, R., Klein, P., Tricker, A.R., 1990. Mutagenic and genotoxic activities of extracts derived from the cooked and raw edible mushroom Agancus bisporus. J. Cancer Res. Clin. Oncol. 116, 475-479.

Queiroz, EAIF, Fortes, ZB, da Cunha, MA.A, Barbosa, A.M, Khaper, N. Dekker, R.F.H 2015. Antiproliferative and pro-apoptotic effects of three fungal exocellular $\beta$-glucans in MCF-7 breast cancer cells is mediated by oxidative stress, AMP-activated protein kinase (AMPK) and the Forkhead transcription factor, FOXO3a. Int. J. Biochem. Cell Biol. 67, 14-24.

Roupas, P., Keogh, J., Noakes, M., Margetts, C., Taylor, P., 2012. The role of edible mushrooms in health: evaluation of the evidence. J. Funct. Foods 4, 687-709.

Serpeloni, J.M., Barcelos, G.R.M., Friedmann Angeli, J.P., Mercadante, A.Z, Lourdes Pires Bianchi, M., Antunes, L.M.G., 2012. Dietary carotenoid lutein protects against DNA damage and alterations of the redox status induced by cisplatin in human derived HepG2 cells. Toxicol. in Vitro 26, 288-294.

Słoczyńska, K., Powroźnik, B., Pękala, E., Waszkielewicz, A., 2014. Antimutagenic compounds and their possible mechanisms of action. J. Appl. Genet. 55, 273-285.

Steluti, R.M., Giese, E.C., Piggato, M.M., Sumiya, A.F.G., Covizzi, L.G., Job, A.E., Cardoso, M.S., Corradi da Silva, M.L. Dekker, R.F.H. Barbosa, A.M., 2004. Comparison of Botryosphaeran production by the ascomyceteous fungus Botryosphaeria sp., grown on different carbohydrate carbon sources, and their partial structural features. J. Basic Microbiol. 44, 480-486.

Strober, W., 2001. Trypan Blue Exclusion Test of Cell Viability, Current Protocols in Immunology. John Wiley \& Sons, Inc.

Sugimura, T., 2000. Nutrition and dietary carcinogens. Carcinogenesis 21, 387-395.

Tice, R.R., Agurell, E., Anderson, D., Burlinson, B., Hartmann, A., Kobayashi, H., Miyamae, Y., Rojas, E., Ryu, J.C., Sasaki, Y.F., 2000. Single cell gel/comet assay: guidelines for in vitro and in vivo genetic toxicology testing. Environ. Mol. Mutagen. 35, 206-221.

Toth, B., 1991. Carcinogenic fungal hydrazines. In vivo (Athens, Greece) 5, 95-100.

Von Borstel, R.C., Drake, J.W., Loeb, L.A., 1996. Foreword. Mutat. Res./Fundam. Mol. Mech. Mutagen. 350, 1-3.

Waters, M.D., Brady, A.L., Stack, H.F., Brockman, H.E., 1990. Antimutagenicity profiles for some model compounds. Mutat Res.Rev. Genet. Toxicol. 238, 57-85.

Weitzenfeld, P., Ben-Baruch, A., 2014. The chemokine system, and its CCR5 and CXCR4 receptors, as potential targets for personalized therapy in cancer. Cancer Lett. 352, 36-53.

Weng, B.B.-C., Lin, Y.-C., Hu, C.-W., Kao, M.-Y., Wang, S.-H., Lo, D.-Y., Lai, T.-Y., Kan, L.-S, Chiou, R.Y.-Y., 2011. Toxicological and immunomodulatory assessments of botryosphaeran ( $\beta$-glucan) produced by Botryosphaeria rhodina RCYU 30101. Food Chem. Toxicol. 49, 910-916.

Williams, G.B.D., 2009. (1,3)-B-Glucans in innate immunity: mammalian systems. In: A.P. (Ed.), Chemistry, Biochemistry and Biology of $(1 \rightarrow 3)-\beta-D-$ Glucans and Related Polysaccharides. Elsevier, pp. 579-619.

Zong, A., Cao, H., Wang, F., 2012. Anticancer polysaccharides from natural resources: a review of recent research. Carbohydr. Polym. 90, 1395-1410. 